\title{
Skryté kurikulum vo svetle metodologického holizmu a metodologického individualizmu
}

\author{
Lukáš Bomba \\ Fakulta humanitných vied Žilinskej univerzity v Žiline
}

Redakci zasláno 1. 8. 2012 / upravená verze obdržena 19.11. 2012 / k uveřejnění přijato

20.11. 2012

\begin{abstract}
Abstrakt: Štúdia analyzuje problém skrytého kurikula v škole ako problém teoretickometodologický. Porovnáva individualistické a holistické prístupy pri skúmaní, meraní a analyzovaní skrytého kurikula. Cielom štúdie je ukázat', že nezrovnalosti $\mathrm{v}$ chápaní a $\mathrm{v}$ definovaní skrytého kurikula pramenia $\mathrm{z}$ jeho paradigmatického neukotvenia, a to ako teoretického, tak metodologického. V štúdii sú teórie skrytého kurikala rozdelené na dve skupiny. Teórie prvej skupiny sú charakterizované ako individualistická paradigma a teórie druhej skupiny zase ako holistická paradigma. Následne sú identifikované v týchto paradigmách základné východiská, $\mathrm{z}$ ktorých vychádzajú. Na príkladoch empirických štúdií sa príspevok snaží ukázat', ako je teoretický základ paradigmy aplikovaný v empirickom skúmaní skrytého kurikula. Prichádzame $\mathrm{k}$ záveru, že definovanie a chápanie skrytého kurikula podmieňuje metodologický prístup jeho skúmania, ktorý spätne vytvára teóriu skrytého kurikula. V individualistickej paradigme je tak skryté kurikulum chápané skôr ako súčast' každodenného procesu implicitnej socializácie diet’at’a cez jednotlivé konanie, či akty jednotlivcov, zatial' čo v holistickej paradigme má skryté kurikulum nadindividuálnu inštitucionalizovanú povahu ako ideológia, či mechanizmus reprodukcie.
\end{abstract}

Klúčové slová: skryté kurikulum, škola, metodologický individualizmus, metodologický holizmus

\section{1 Úvodom}

Socializačný a výchovno-vzdelávací proces $\mathrm{v}$ škole $\mathrm{v}$ sebe nesie vždy na jednej strane zjavné, na strane druhej skryté aspekty. Zjavným je celé pole poznatkov, informácií a nadobudnutých vedomostí, rovnako tak aj zručností ako písanie, čítanie, počítanie a výchovné štýly. Nezjavnými, inak povedané skrytými aspektmi socializácie a vzdelávania, zostávajú obsahy, hodnoty, pravidlá správania sa či skúsenosti, ale aj hodnoty a postoje, ktoré sa žiak naučí a interiorizuje, ktoré môžu, no nemusia tvorit’ obsah učebného plánu. Skryté kurikulum nie je výsostne problémom pedagogiky ako vednej disciplíny. Touto problematikou sa zaoberajú aj sociológia výchovy a rovnako tak aj sociálna psychológia. Myslím si, a nie som sám (napr. Kaščák \& Filagová, 
2007), že skrytému kurikulu nebola doteraz venovaná náležitá pozornost'. Pri tejto problematike väčšinou skončíme pri konštatovaní, že skryté kurikulum existuje a žiaci si ho v škole osvojujú. Problematika skrytého kurikula „nadobudla podobu akejsi všetko absorbujúcej teórie - čo je, samozrejme, nezmysel“" (Kaščák \& Filagová, 2007, s. 24).

Mojou snahou v tomto článku je predstavit’ problém skrytého kurikula, ktorý je nejednoznačne chápaný a široko definovaný ako problém teoretickometodologický. Problém chcem riešit' tak, aby moje uchopenie poskytovalo metodologický priestor a predpoklad pre výskum skrytého kurikula. Myslím si, že skryté kurikulum nemôže byt' skúmané z pozície substancializmu. Vsadenie problematiky do kontextu rôznych teórií ( $\mathrm{v}$ širokom chápaní tohto pojmu) a jeho definovanie ako problému metodologického načrtne možné vysvetlenia prítomnosti skrytého kurikula v škole ako v špecifickej inštitúcii. Rovnako tak umožní aj posun ako vo vysvetlovaní fungovania a dynamiky školského prostredia, tak aj $\mathrm{v}$ dôsledkoch, ktoré nesie jeho existencia. Štúdia je omnoho bližšia pohladu sociológie výchovy ako pedagogiky, čo vyplýva z autorových obmedzení v tejto téme, ktoré sú dané profesionálnym zameraním.

\section{$2 \quad$ Skryté kurikulum - čo ním vlastne myslíme?}

Pojem skryté kurikulum sa odvodzuje od kurikula formálneho. Formálne kurikulum je široko povedané obsah vzdelávania, ktoré žiaci získavajú v škole. Průcha (2002, s. 243) upozorňuje, že v pedagogike sa chápe kurikulum v zásade dvoma spôsobmi. Bud” „prakticky v zmysle konštruovania a analýzy konkrétnych kurikul a ich správania sa v reálnom edukačnom procese, alebo po druhé ako získané skúsenosti“. Tak isto vieme, že v škole žiaci nezískavajú len poznatky a skúsenosti, ktoré boli plánované, ale dostáva sa im ovela viac. Toto „ovel'a viac“ nevieme presne uchopit', už napríklad len preto, že nie je ujasnené, či týmto pojmom budeme mysliet' to, čo bolo žiakovi odovzdané, alebo to, čo bolo žiakom zvnútornené - kurikulum ústretové a kurikulum sprostredkujúce (Maňák \& Janík, 2009, s. 117).

Hranicu medzi skrytým kurikulom a kurikulom formálnym (najmä čo sa týka jeho zvnútornenej stránky u žiaka) je nel'ahké stanovit'. Samotné výučbové plány (oficiálne formálne kurikulá) sú plné informácií a obsahov, ktoré boli a sú často kritizované spoločenskými vedcami za to, že umožňujú, alebo priam sprostredkujú reprodukciu tried, genderových, rasových a d'alších nerov- 
ností. Príkladom môže byt' článok od Matusa a McCarthy (2003), ktorí kritizujú etnocentrizmus školských kurikúl. Hovoria, že školy tým čo učia, vytvárajú kultúrnu bariéru medzi „starým obyvatel'stvom“ Spojených štátov amerických, emigrantmi a krajinami tretieho sveta. Takýto stav umožňuje deformované chápanie kultúry ako jazyka, estetiky a folklóru. Zabúda sa na to, že kultúra je fenomén ovplyvňujúci každý l'udský akt. Samotné formálne kurikulá prechádzajú zmenami a reformami, pretože sú považované za zastarané či slúžiace ideológii. Smith (2003) hovorí, že v posledných desat'ročiach sa vzdelávanie a vzdelávací systém zmenili. Zdôrazňuje sa úspech namiesto kultivovania, deregulujú sa profesijné učitel'ské odbory pre zvyšovanie sútaženia medzi učitel'mi, vzdelávacie kurikulum sa externalizuje a na jeho vytváraní sa podiela čím d’alej tým viac inštitúcií, ktoré so vzdelávaním bezprostredne nesúvisia. Vzdelávacie kurikulum zároveň musí slúžit’ potrebám globálneho kapitalizmu, oddel'ujú sa témy „učenia sa a vyučovania“ od témy „školského manažmentu“ atd'. (Smith, 2003, s. 38). Formálne kurikulum sa prelína v efektoch svojej prítomnosti v spoločenskej a edukačnej realite so skrytým kurikulom. Práve túto skutočnost' vybadali a do nej vsadili svoje výskumy tí, čo odvodzujú chápanie skrytého kurikula od jeho vplyvu na školskú úspešnost' žiaka (napr. Joughim, 2010; Becker, Geer, \& Hughes, 1968, cit. 1995; Snyder, 1971; Miller \& Parlett, 1974). Na druhej strane d'alší chápu skryté kurikulum v omnoho širšej perspektíve (napr. Apple, 1990; Giroux, 1981; ale aj Illich, 1973). Ako uvidíme neskôr, obsah skrytého kurikula je chápaný aj ako obsah ideológie prevládajúcej v spoločnosti.

Je t’ažké potom súhlasit’ so Švecom (2008), ktorý prekladá a definuje pojem skryté kurikulum ako „obsah vzdelávania a výcviku, ktorý si žiaci či študenti osvojujú mimo predpísaného učiva predmetov učebného plánu a učebných osnov... implicitná socializácia..." (Švec, 2008, s. 130). Pojem skryté kurikulum sa však takto dostáva do roviny, ked' skrytým kurikulom môže byt' všetko, s čím sa neráta, že si deti v škole osvoja, alebo čo sa im odovzdá. Presne takto, ako všetko s čím sa neráta, ho vymedzuje Bergenhenegouwen, ked' vo svojom článku o skrytom kurikule v univerzitnom prostredí hovorí, že skryté kurikulum je „Všetko, čo nie je obsahom oficiálneho vzdelávania“ (Bergenhenegouwen, 1987, s. 536). Teória skrytého kurikula je však v takomto chápaní pojmu ukotvená v pasci „obsahu“ a substancializmu, (a aj to iba na rovine elementárnych aspektov sociálneho usporiadania (obsah, skúsenost', socializácia...), čo predpokladá vedecké vysvetl'ovanie pomocou vymenovania prvkov. Navyše pre nepresné definovanie pojmu by sme nevedeli skúmat' ani jeho prítomnost' v spoločenskej a edukačnej realite. 
Rovnaký problém nesprávneho ukotvenia teórie kritizovali už Giroux a Penna (1979), ked' hovoria, že je potrebné nepozerat' sa na vyučovanie a učenie technicky ahistoricky, ale cez socio-politickú perspektívu. Vztahy a celková dynamika zostávajú $\mathrm{v}$ takto substancionalistickom, ahistorickom a technickom probléme nereflektované a nereflektovatelné. Dnes stále chápeme školu viac ako miesto socializácie diet’ata a žiaka a už menej ako aktéra socializácie a vlastne tu má celý problém korene. „Školy totiž neučia len „poznanie“, ale učia aj „deti“ (Apple, 1990, s. 15).

Pokial' vychádzame z rozdelenia teórií skrytého kurikula, ktoré $\mathrm{v}$ našom prostredí kvalifikovane poskytli Kaščák a Filagová (2007), vidíme teórie, o ktorých hovorí Ondrejkovič (Beck, Zinnecker, Tillmann) zaoberajúce sa skrytým kurikulom v kontexte výchovy ku konformite voči „vláde kapitálu“ (Ondrejkovič, 2004, s. 148-151) cez prizmu kritických prístupov. Následne sa nám javí aj LeCompte (1978) v staršom, ale výnimočnom článku o „Učení k práci..."vel'mi podobne a tiežju zarad'ujeme medzi kritické prístupy. LeCompte vel'mi detailne na každodenných výchovno-vzdelávacích postupoch učitelov ukazuje, že napriek ich rôznorodosti dospievajú k rovnakému výsledku. V krátkosti je možné zhrnút' jej článok takto: Zadávaním úloh (v škole aj na domov) a kontrolou a vyžadovaním ich plnenia sa diet'a učí nielen učivo, ale rovnako tak aj zodpovednosti, načúvaniu príkazom vyššie postaveného a celkovo „životu v inštitúcií“. Rovnako tak zaradíme ku kritickým prístupom aj prácu Langhout a Mitchell (2008). Autorky vo svojej štúdii ukazujú, ako sa prenáša skryté kurikulum rasizmu a genderu v školskej triede priamo vo vyučovacom procese. Každodenné konanie učitel'ky, jej kontrola, zadávanie úloh, kontrola ich plnenia a udržiavanie poriadku a disciplíny $\mathrm{v}$ triede umožňujú reprodukovat' rasové a genderové stereotypy $v$ nerovnakom prístupe ku žiakom či v nerovnakých reakciách na ich správanie.

Dostali sme sa takto k bodu, ked' môžeme skryté kurikulum chápat' výsostne pedagogicky, a teda cez prizmu akýchsi dôsledkov pre edukačnú realitu, ktoré samozrejme realitu ovplyvňujú a vytvárajú tak aj aspekt príćinnosti. Metodologicky takto vieme uchopit' problém skrytého kurikula cez školy funkcionalizmu, marxizmu, neomarxizmu, či symbolického interakcionizmu.

Mareš a Rybářová (2003) identifikovali v teóriách skrytého kurikula vzorec, podla ktorého je skryté kurikulum chápané 1 . ako niečo zlé, utajované, skrývané, čo vládnucej spoločnosti slúži na to, aby udržovala sama seba a svoje hodnoty; 2 . ako neutrálny pojem, ktorým sa bádatelia snažia uchopit' a preskúmat' to, čo sa odohráva mimo zjavné oficiálne programy v každo- 
dennom živote školy (Mareš \& Rybářová, 2003, s. 102). Takýto náhlad na skryté kurikulum nás priblíži k jadru tejto štúdie. Na jednej strane vidíme aspekt spoločnosti, ktorá sama seba reprodukuje cez svoje súčasti, aby sa vrátila k východiskovému bodu. Vidíme tu akúsi cyklickost'. Na druhej strane konanie (jednotlivcov) v škole, ktoré sa odohráva každodenne, je premenlivé a môžeme v ňom nájst' určitú lineárnost'.

Problematika skrytého kurikula v škole je, už bez ohl'adu na to z pohl'adu akej teórie na ňu pozeráme, zviazaná s prvkami vlastnými škole a s vyučovacím procesom. Na školu je však nevyhnutné pozerat' sa ako na široký inštitucionálno-organizačný priestor, viac či menej ukotvený v spoločenskej situácii. Upozorňujú na to aj Havlík a Kotá (2007, s. 114-115) a Costello (2001), ktorá vo svojom článku rámcuje skryté kurikulum do školy ako priestoru a upozorňuje, že aj na chodbách školy sa stretávajú študenti a žiaci s informáciami, ktoré im odovzdávajú skúsenosti i poznatky do d’alšieho života. Čo ukázala Costello je fakt, že skryté kurikulum nemusí byt' explicitne obsahom vzdelávania. Tabul'ky s menami finančných darcov tvoria súčast' vnútorného zariadenia budovy školy a ich funkciou je odovzdávat' odkaz o vd'ake bývalých absolventov školy a tým vedú aj mladších absolventov ku takémuto konaniu v budúcnosti. „Mimovzdelávacie“ skryté kurikulum priblížil aj Prosser (2007) v článku, v ktorom hovorí o vizuálnej stránke školy. Videné z tejto perspektívy sa dá hovorit’ o tom, že existuje rozpor v definícii skrytého kurikula a v dôsledkoch, ktoré má jeho prítomnost' v škole.

Môžem d’alej pokračovat' a ukázat' dalšie zaujímavé výskumy a pokusy o definovanie $\mathrm{v}$ oblasti skrytého kurikula, ktoré boli do dnešnej doby realizované a ktoré sa snažia definovat' skryté kurikulum. Všimnime si ale, čo majú spoločné výskumné snahy citovaných autorov. Skryté kurikulum nie je len pojmom, ktorý používajú pre vysvetlenie školskej reality, ale pojem vždy dostáva určitú híbku a šírku. Pojem skrytého kurikula je vsadený do rôznych rámcov a použitý ako centrálny bod výskumu, od ktorého sa odvíjajú vysvetlenia triednych, rasových či genderových nerovností, problematika prostredia školy (klímy školy), alebo výchova k hodnotám súčasnej doby. Samotná definícia skrytého kurikula závisí teda vždy od pohladu na tento fenomén, od príčin a dôsledkov jeho existencie. Skryté kurikulum je pojem s nejednoduchým a nejednoznačným chápaním. V nasledujúcej časti textu sa pokúsim ukázat’ pojem skrytého kurikula vo svetle metodologického individualizmu a metodologického holizmu. 


\section{Problém individualizmu a holizmu}

Metodologicky je možné uchopit’ problematiku skrytého kurikula na jednom jednoduchom príklade. V roku 2004 bola v Prahe putovná európska výstava malovaných kráv (Cow Parade). V parku na Kampě bolo umiestnených 25 kráv v kruhu symbolizujúcich jednotu Európskej únie, pomalovaných rôznymi „národnými motívmi“ od holandskej krajinky, cez španielske národné symboly až po vlajku Európskej únie. Jedna krava však bola úplne odlišná od tých ostatných. Bola to krava, ktorá symbolicky patrila Slovensku. Na tejto krave bola na základnom bielom podklade namalovaná dobre známa detská hra pre rozvíjanie obrazotvornosti. Jednotlivé body, ktoré sú očíslované od jednotky, je potrebné spojit’ čiarami a tie vytvoria obrázok, ktorý oko diváka nevidí, kým body ruka nepospája. Metodologický individualista sa na túto kravu môže pozerat' a následne skonštatovat', že jednotlivé body sú vo vzájomnom vztahu, viac či menej podobnom a tieto vztahy a body vytvárajú kravu. Metodologický holista sa zase pozrie na kravu a skonštatuje, že krava je kravou práve kvôli tomu, že spojením jednotlivých bodov čiarami je vytvorená nová kvalita, ktorá dáva inak nezmyselnej mäteži bodov a čiar „dušu“. Metodologickí individualisti sú často slepí voči štruktúrnym zákonitostiam a metodologickí holisti zase nevidia kvalitu a rôznost' jednotlivých vztahovov medzi bodmi, prípadne devalvujú individuality na „otrokov“ štruktúry.

Ondrejkovič $(1998,2004)$ vymedzuje štyri skupiny socializačných teórií. Teórie socializácie sa líšia tým, akú úlohu v procese socializácie pripisujú jednotlivcovi. Rovnako tak môžeme nazerat' na skryté kurikulum. Teórie skrytého kurikula počítajú s rôznou mierou odovzdanosti, reflexie či prispôsobovania sa žiaka spoločnosti (systému, skupine atd'). Pokial' holistická skupina teórií vidí, že problematika skrytého kurikula vyrastá z existencie dominantnosti celku nad individualitou, individualistická skupina zdôrazňuje individuálne prispôsobovanie sa a individuálne konanie jednotlivca celku. (Stačí si spomenút' na jednej strane na reprodukciu kultúrneho kapitálu v škole u Bourdieho a na strane druhej na prácu Meada a jeho vysvetlenie seba-ponímania ako „I“ a „ME“ a aplikovat' ho do školskej triedy a jej života).

Skryté kurikulum je tiež možné vysvetl'ovat' na škále dvoch pohladov a to radikálne holistického a radikálne individualistického. Radikálny individualizmus je charakteristický zdôrazňovaním role jednotlivca, vysvetlovaním z pozície psychologizmu, pričom postupuje od časti k celku, od jednotlivca k javu systému, je charakteristický redukcionizmom, sumáciou a agregáciou. Radikálny holizmus zdôrazňuje rolu celku ako nadinviduálneho javu, je cha- 
rakteristický antiredukcionizmom a emergenciou, vysvetl'uje javy zo sociologistickej perspektívy a postupuje od celku k časti, od systému k jednotlivcovi (pozri bližšie Schenk, 2009, s. 78).

Perspektívy holizmu a individualizmu sa dajú d'alej rozlíšit'. Vždy totižto môžeme hovorit' o metodologickom holizme a metafyzickom holizme. Na druhej strane o metodologickom individualizme a metafyzickom individualizme. ${ }^{1}$ Metodologický holizmus trvá na tom, že sociálne javy je nutné študovat' na makroskopickej úrovni analýzy. Jednotlivci sú totiž tým, čím sú práve kvôli sociálnemu celku, ku ktorému prináležia (Fay, 2002, s. 67). „Makrofenomény sú agregátnymi entitami vytvorenými z jednotiek alebo elementov „podriadeného" usporiadania. Ked' sa spoja (skombinujú), vyústia udalosti svojou povahou do udalosti makroskopickej, ktorá je predmetom výskumu“ (Rios, 2005, s. 773). „Metafyzický holizmus zase tvrdí, že existuje metafyzická priorita celku nad čast’ami, že celok predstavuje pravé súcno, zatial' čo časti len súcno nepravé" (Německý, 2008, s. 164). Inak povedané: Jednotlivci sú len agenti, ktorými hýbe celok.

Perspektíva metodologického individualizmu a jej predstavitelia, ktorí odkazujú ku sociálnym celkom, sú presvedčení, že takéto celky je možné zredukovat' na aktivity a stavy jednotlivcov (Fay, 2002, s. 46). Povedané inak: „Pravidelnosti v usporiadaní, ktoré študuje makrosociológia sa musia chápat' ako súhrnné výsledky vznikajúce z kolektívnych individuálnych konaní" (Rios, 2005, s. 773). Čitatel' už určite vie, ako bude definovaný metafyzický individualizmus. Jednotlivec je integrovaná bytost', nevystupujúca z celku, s dostatočným odstupom od ostatných jednotlivcov, pričom v minimálnej interpretácii sa jednotlivca celok takmer nedotýka, v maximálnej interpretácii celok neexistuje.

Ďalej sa budem venovat' už len prístupu metodologického holizmu a metodologického individualizmu, tie sú totiž jadrom celého článku. Metafyzické prístupy vyčlením na okraj môjho záujmu. V článku chcem ukázat' postupy metodologického myslenia o skrytom kurikule, nepátram po dimenziách jeho ontologickej dominancie. Skryté kurikulum je konceptom, ktorý označuje, ako som už povedal, fenomén, na ktorého vysvetlenie príčinnosti a dôsledkov môžu slúžit' teórie o fungovaní spoločnosti (holistická perspektíva) či sveta človeka (individualistická perspektíva), poskytujú totiž interpretačný rámec skrytého kurikula.

1 Ďalšia explanácia je zjednodušená. 


\section{$4 \quad$ Skryté kurikulum v individualistickej perspektíve}

$\mathrm{V}$ tejto kapitole mi nejde o podrobné skúmanie všetkých individualistických teórií, ktoré čitatel' už pozná. Budem sa snažit' ukázat' ako je, alebo môže byt', skryté kurikulum uchopené v tejto paradigme (týchto paradigmách). Tieto paradigmy popisujú javy spoločenskej povahy na mikroúrovni. Zaoberajú sa každodenným prežívaním, interakciou jednotlivca s jednotlivcom a hlavne pravidlami a štruktúrami konania a správania sa človeka. Neriešia teda vysoko abstraktné usporiadanie spoločnosti ako celku a jej súčastí, systémov a subsystémov.

Meno Harolda Garfinkela sa spája s teóriou etnometodológie². V„základnej“ knihe tejto koncepcie Garfinkel (1967) vysvetl'uje, ako je v l'udskej interakcii pripisovaný význam jednotlivým úkonom človeka $\mathrm{v}$ tejto interakcii, jeho správaniu sa a konaniu, ako je každý takýto akt interpretovaný a ako je celým týmto procesom vytváraný sociálny svet. Petrusek (2000, s. 176) d’alej upozorňuje, že zmysel reality je podla etnometodológie produktom rečového aktu, interakcia je redukovaná na komunikáciu a funguje nielen na základe verbálneho prejavu, ale aj tzv. background expectations (očakávania v pozadí). Táto koncepcia sa stáva zaujímavou a stojacou za použitie pri riešení otázok, ako funguje komunikácia učitela so žiakmi v škole, kde sú limity komunikácie, ako postupovat' v pedagogickej praxi tak, aby žiaci pochopili to, čo si učitel' želá, napr. nazerat' na ranné obdobia socializácie diet'ata v škole cez etnometodologický prístup by mohlo práve v kontexte skrytého kurikula ukázat' nezvyčajne inšpirujúce poznatky. Deti prichádzajú do školy ako prváci a stávajú sa žiakmi. Čerpajú background expectations o učitelovi z rozprávania rodičov, známych, z predchádzajúcich skúseností a pod. Prvé konfrontácie a poznávanie učitel'a z pozície žiaka prinášajú pre diet’a - žiaka skúsenosti, napr. o role učitela, správaní sa učitela, reakciách učitel’a na rôzne situácie počas vyučovania. Interpretácia a interiorizovanie nových znalostí a skúseností je vlastne učenie sa skrytému kurikulu v inštitúcii, do ktorej diet’a prišlo.

George Herbert Mead bol známym americkým spoločenským vedcom a sociálnym psychológom. Medzi jeho najznámejšie diela patrí Mind, Selfand Society. Jeho meno je známe aj v pedagogike najmä preto, že v jeho diele má dominantné postavenie socializácia. Jednotlivec sa jednotlivcom nenarodí, stáva

2 Garfinkel a ani za ním nasledujúci Mead nikdy nepísali o skrytom kurikule v škole, ich prístupy tu spomínam ako možné metodologické prístupy pre riešenie otázok skrytého kurikula. 
sa ním počas vývinu (Mead, 1934, s. 135), čo je základná téza symbolického interakcionizmu. Vd’aka tomu, že jednotlivec si uvedomuje svoju vlastnú existenciu, existenciu druhého a súčasne, že druhý si je vedomý existencie práve jednotlivca, sú dôležitými poznatkami tejto paradigmy. Koncept druhého mal d’alekosiahle dôsledky pre chápanie jednotlivca tak, ako ho chápeme dnes. Rovnako tak aj rozdelenie chápania seba na „I“ (moje vlastné ja) a „ME“ (sociálne štruktúrované ja). Postava učitela je vždy postavou druhého, voči ktorej si každý žiak interiorizuje a definuje postoj. Skúmanie skrytého kurikula v tejto teórii môžeme uplatnit' na každom mieste stretnutia jednotlivca s jednotlivcom v štruktúre školy. V každodennom stretávaní sa učitel'ov a žiakov, ich nazeraní na samých seba a na tých ostatných, preberaní postojov, vyrastaním žiakov pri spolunáležitosti s učitel'mi, z ktorých každý jeden má rôzne rodinné, finančné, triedne, hodnotové, etické, geografické atd'. zázemie, znamená možnost' pre pedagogiku v každom jednom momente hladat' a nachádzat' odpovede, ako presne (akými cestami) sa prenáša skryté kurikulum. Koncepcia Meada nedokáže zodpovedat' otázky o tom, prečo dochádza k takým či onakým spoločenským javom. Ked' čítame Meada, nikdy nevidíme široký a hlboký obraz krajiny so vztahmi medzi objektmi na obraze. Jeho koncept je silný pri sledovaní mikroakcií a zákonitostí fungovania interakcie.

Fenomenológia je škola, z ktorej čerpajú jednak etnometodológia, tak aj symbolický interakcionizmus. Najznámejším predstavitelom fenomenologickej sociológie bol Alfred Schütz. Škola je životným priestorom človeka, ktorý je súčast'ou životného sveta (Lebenswelt), „,...ktorý označuje skutočné aj možné horizonty človeka" (Petrusek, 2000, s. 166). L’udia žijú v životnom svete, interpretujú ho a individuálne konajú, tým potvrdzujú existenciu sveta a vytvárajú ho. Interpretáciu a konanie predchádza poznanie, ktoré vo fenomenologickej sociológii naberá podobu balíku príručného vedenia, ktorý je v životnom svete vždy pre jednotlivca pripravený a on ho preberá a riadi sa ním, pretože umožňuje nájst' poriadok v možnom chaose. Mikrorovina l'udskej existencie je polom, na ktorom stretávame interpretácie fenomenologickej sociológie. Nepýta sa na to, ako ovplyvní školu školský zákon. Pozerá sa na svet cez vnem jednotlivca. Ako sa pozerá jednotlivec na školu, na učitel'ov, na spolužiakov, na základe čoho ich rozpoznáva? Ako interpretuje (chápe) ich postavenie či rolu? Ako chápe ich osobnosti? Toto sú otázky, ktoré je možné zodpovedat' s pomocou tejto teórie. Skúmanie klímy školy, v pedagogike tak moderné, je skúmaním chápania životného priestoru samotnými aktérmi tohto priestoru. Je možné otvorit' tento priestor fenomenológie, íst' d’alej a neskončit' len pri skúmaní atmosféry a klímy školy. 
Mareš a Rybářová (2003) sa vo svojom článku o skrytom kurikule na vysokej škole blížia k paradigme fenomenológie. Skúmali dopady skrytého kurikula na osobnost' študentov, na organizačný chod fakulty, dopady pedagogickej činnosti učitel'ov a dopady práce so študijnými materiálmi. Autori rámcujú skryté kurikulum na týchto operacionalizovaných premenných do kontextu lekárskej fakulty. V článku zachytili v každodennosti života študenta jeho „priúčanie“ sa svetu fakulty, postupom, práci, kontaktu s ostatnými a ukazujú hlavne fakultu cez pohlad študenta.

Inšpiratívnou teóriou pre skúmanie skrytého kurikula je aj takzvaná teória dramaturgického konania, s ktorou prichádza Goffman, pričom sa nechce zaoberat' „štruktúrou sociálneho života, ale štruktúrou skúseností indivíduí" (Goffman, 1974, s. 13). V jeho najznámejšej knihe (1959, cit. 1999) na vyjadrenie nazerania na svet používa metaforu divadla. Zákulisie a scéna, masky, vytváranie dojmu, presvedčenie o roli, dištancia od role, kulisy a d’alšie sú pojmy, ktoré používa vo svojej teórii. Prvý a vel'ký význam Goffmana vidím, napríklad pri probléme dištancovania sa od role v kontexte skrytého kurikula. Predpokladom, ktorý vyplýva z teórie je, že s čím menším počtom učitelov sa jednotlivec $\mathrm{v}$ živote stretol a interagoval, tým menšiu (skreslenejšiu) predstavu má o náplni role učitel'a. Výkony jednej role u mnohých učitelov sa niekedy $\mathrm{v}$ detailoch, inokedy podstatne líšia. Goffman poukázaním na tento fakt ukazuje, ako je podstatné odlišovat' rolu a výkon role. Zmätenost' v ich chápaní je priestorom pre pripisovanie osobnostných charakteristík učitela roli učitel'a. Tu, v každodennej interakcii role a role, jednotlivca a jednotlivca je možné opät' pátrat' po konkrétnych akciách - konaní a správaní sa týchto jednotlivcov a ich interpretácií (ktoré sú vždy predpokladom d'alšieho konania) týchto akcií. Aj táto teória je vitrážou mozaiky fungovania sociálneho sveta na mikroúrovni.

Na Goffmanovu teóriu nadväzujú v Nemecku a v Rakúsku Zinnecker (1978) a Wagner-Willi (2005). V Spojených štátoch amerických Corsaro (1988), ktorý identifikoval v živote materskej školy stratégie detí, ako nebyt' „len žiakom“. Na Slovensku čiastočne vychádzajú z diela Goffmana Kaščák a Filagová (2007). Autori analyzujú prostredie materskej školy a na detailoch každodenného života ukazujú, ako sa deti učia spoločnému životu v kolektíve cez prispôsobovanie sa ostatným žiakom, ako sa učia disciplíne, rešpektovaniu autority a organizácii práce. Následne na mikrorovine každodenných aktivít autori popisujú genderovo podmienené správanie sa učitel'ky voči dievčatám a chlapcom. Genderovo rozdielny prístup učitel'ky ku žiakom dvoch rodov sú pre autorov podkladom pre ukázanie jednotlivých situácií v škole, ktoré 
implikujú svoju pravidelnost' a tým v konečnom dôsledku vytvárajú rozdielne výchovné postupy.

Aplikáciu metodologického individualizmu môžeme nájst' aj v práci Jacksona (1966). Narába s troma pojmami - pozdržanie (delay), odmietanie (denial) a prerušenie (interruption). Ukazuje, že diet'a sa v škole učí čakat' na ostatných, musí sa zmierit' s nevšímavost'ou druhých, alebo si vybojovat' pozornost'. Diet’a sa učí, že formálne vyučovanie netvorí celok, ale je mnohokrát prerušené situáciami, ktoré nie sú tak povediac „inštitúciou dané“. Zámerom autora bolo ukázat', že škola sa riadi aj inými pravidlami ako len oficiálnym kurikulom. V škole existuje aj skryté kurikulum „pravidiel, regulácií a rutiny a vecí, ktoré sa učitelia a žiaci musia naučit', ak chcú zvládnut' inštitúciu školy „bez ujmy“ (Jackson, 1966, s. 353).

Individualistické teórie ukazujú, ako môžeme skúmat' konanie jednotlivcov - aktérov v škole. Každá jednotlivost' ukazuje iné stránky, nie je teda možné jednu redukovat' na druhú, aj ked' sa ich východiská či závery navzájom približujú. Prístupy, vychádzajúce z každodennosti prežívania l'udí, či interakcie medzi nimi, môžeme použit' na sledovanie reality, pretože teórie poskytujú nástroje na to, ako uchopit' to, čo vidíme. Generalizovat' poznatky z výskumu v týchto perspektívach a tým sa vraciam k otázke metodologického individualizmu, môžeme práve vd'aka tomu, že v prípade ak je jednotlivec súčastou spoločnosti a zároveň jej tvorcom (a on nim v týchto paradigmách je), môžeme jeho konanie a správanie sa generalizovat' až po všeobecné pravidlá fungovania spoločnosti. $V$ tomto článku mi nezáleží na tom, či spomínané teórie vychádzajú z predpokladu rozporov a konfliktov v školskom systéme, alebo na druhej strane vysvetl'ujú prenášanie určitých noriem v spoločnosti, ich metodologický postup je rovnaký v bode „každodennosti“. Akty konajúcich, v prípade skrytého kurikula v prvom rade učitel'ov a žiakov, vytvárajú štruktúry, ktoré slúžia a fungujú ako predpoklady, modely a formy pre d’alšie správanie sa jednotlivých konajúcich. Výskumníci, vychádzajúci z týchto teórií a samotné individualistické teórie aplikované vo výskume skrytého kurikula aj po inšpirácii konfliktualistickými teóriami, napr. triednych rozporov, dokážu ukázat', aké sú „pravidlá“ správania sa na mikroúrovni, avšak bud' nevysvetl'ujú, prečo sa tak deje (aký je význam pohybu na vyššej úrovni), alebo robia závery pre poznatky na vyššej úrovni z tých na nižšej úrovni. Pre vysvetlenie širších okolností fungovania skrytého kurikula teda treba zodpovedat' otázku, prečo sa ním vlastne zaoberat' a zároveň prečo, na čo a komu slúži skryté kurikulum, pričom tieto teórie sú už vel’akrát nedostačujúce. 


\section{$5 \quad$ Skryté kurikulum v holistickej perspektíve}

Myslím si, že samotný koncept skrytého kurikula sa dostáva do pedagogiky vtedy, ked' sme si uvedomili, že deti si zobrali zo školy aj niečo viac ako len učivo. Je t'ažké povedat', že či to bolo pred tým alebo potom, ako si zase sociálni vedci uvedomili, že existujú princípy fungovania spoločnosti, cez ktoré spoločnost' reprodukuje, či rozvíja sama seba. Už nech to bolo akokolvek, skryté kurikulum, ako som už skôr povedal, potrebuje koncept - rámec, ktorý nám dokáže objasnit' otázku, prečo vlastne skryté kurikulum existuje. Teórie, na ktoré zase v krátkosti upozorním v tejto kapitole, sa nezaoberajú konaním učitel'ov a žiakov v škole. Aktéri a ich konanie sú v teóriách daní apriori a pre teórie z hl'adiska vysvetlovania viac či menej ako individuality nepotrební.

Louis Althusser bol marxistický filozof, dnes u nás prakticky zabudnutý, výborný študent diela Marxa a učitel’ známeho Foucaulta, ktorý zanechal americkej kritickej škole pedagogiky hlboký odkaz. Na čo je potrebné upozornit' pri diele Althussera, je jeho rozdelenie štátnej moci na štátny aparát a ideologický štátny aparát. Kým štátny aparát je represívnou zložkou verejnej moci a zahŕňa vládu, armádu, administratívu, políciu, súdnictvo a väzenstvo, ideologický štátny aparát rozdeluje Althusser na náboženský, vzdelávací, právny, politický, trhový, kultúrny a masovokomunikačný štátny aparát, pričom posledný menovaný nie je typický len pre verejnú, ale aj súkromnú sféru (Althusser, 2008, s. 15-22). Ideologický štátny aparát moci reprodukuje vztahy v spoločnosti a tým aj daný stav. Existuje snaha nemenit’ daný stav vecí, prípadne zamedzit' snahe o zmenu, pretože vyhovuje tým, ktorí majú v systéme najväčšie výhody. Škola takto v teórii Althussera plní funkciu legitimizátora postavenia jednotlivých aktérov (jednotlivcov či spoločenských tried). Althusser priamo nehovorí, ako konkrétne sa dominantná ideológia prenáša v každodennosti školy a nevstupuje pri týchto vyhláseniach na pôdu školy. Obmedzuje sa na tvrdenia, že škola (a cirkev) používajú metódy trestov, vylučovania, selekcie, atd'. „.... to nie len pastierov, ale aj stáda“ (Althusser, 2008, s. 19). Inak povedané, autor tvrdí, že moc vyvinula mechanizmy pre svoju vlastnú reprodukciu a jedným z tých mechanizmov je vlastne škola. Skrytým kurikulom v škole je tak „reprodukcia vztahov produkcie“. Autor osobitne nezdôvodňuje, ako konkrétne sa v školách reprodukuje vládnuca ideológia. Tento stav konštatuje na základe pozorovania reprodukcie znakov spoločenskej reality. 
Pierre Bourdieu je jedným z tých, ktorí sú známi nie len v sociológii,či etnológii, ale aj v pedagogike. Dielom La reproduction (1970, cit. 1990), ktoré napísal s Jeanom-Claude Passeronom, ako aj v diele Les héritiers (1964), zmenil nazeranie na školu ako výchovno-vzdelávaciu inštitúciu. Autori pracujú s konceptom kapitálu, pričom rozpoznávajú jeho tri (neskôr štyri) druhy, ktoré fungujú v sociálnom svete samostatne, každý na vlastnom poli. Ich nadobúdanie sa riadi pravidlami, ktoré sú výhradne uplatňované na tom poli, ku ktorému jednotlivé druhy kapitálu prináležia (bližšie pozri Bourdieu, 1998). Všetky druhy kapitálu sú však navzájom zamenitel'né. (Zaplatenie školného na prestížnejšej škole $\mathrm{v}$ americkom školskom systéme znamená „lepšie“ vzdelanie pre diet'a. Investovanie ekonomického kapitálu teda prináša kultúrny a sociálny kapitál). Bourdieu a Passeron (1990) sú presvedčení, že deti z nižších spoločenských vrstiev prichádzajú do školy s nižším podielom kultúrneho kapitálu oproti det’om z vyšších spoločenských vrstiev. Škola túto nerovnost' d’alej reprodukuje a prehlbuje, tým sa udržiavajú nerovnosti medzi det'mi až do dospelosti, kedy na základe toho, čo sa naučili v škole, získajú prácu. Týmto „základom“ sú jednak formálne garancie (tituly, osvedčenia, diplomy...) a tak isto aj neformálne schopnosti (šikovnost', schopnosti, vedomosti...), ktoré ale nemal každý rovnakú možnost’ získat'. Navyše do tohto problému vstupuje sociálny kapitál, ktorý rozkladá rovnost' príležitostí svojou povahou. Bourdieu a Passeron nehovoria o skrytom kurikule v škole. Ich teória z perspektívy pedagogiky skôr predpokladá, že v škole existuje niečo ako skryté kurikulum, v opačnom prípade by sociálny svet nevyzeral tak, ako vyzerá. $S$ istou mierou nadsadenia je možné povedat', že kultúrny kapitál, ktorý si žiaci a učitelia prinášajú do školy, funguje v edukačnej realite ako skryté kurikulum. Autori nedávajú dôraz na každodenné činnosti a akty. Skôr sa dá povedat', že vidia obsahy vzdelávania a výchovy, ktoré si svojou inštitucionalizovanou povahou vynucujú triedne fungovanie spoločnosti.

Rovnako o fungovaní celku hovorí aj Michael Apple vo svojej známej knihe Ideology and Curriculum (1990). Autor vysvetl'uje, že školy fungujú v systéme viacerých inštitúcií neraz s výraznejšou mocou (politickou, či ekonomickou) ako školy samotné, pričom sa musia prispôsobovat' aj fungovaniu týchto inštitúcií. Pokial' sa ostatné typy inštitúcií (politické strany, trh a ekonomické subjekty atd'.) snažia presadzovat' svoje mocenské záujmy (udržanie moci a prosperity, či ich rozšírenie), ovplyvňujú a spoluvytvárajú školský systém. Zároveň obsahy toho čo sa vyučuje v školách sú obrazom toho, kto ich napísal, prípadne nechal napísat'. Vyššie triedy vytvárajú pomyselnú mriežku vhod- 
nosti, akceptovatel'nosti, správnosti, prijatel'nosti... konania a správania sa, ktorá je vsadená do učebných osnov a všetci žiaci sú s ňou konfrontovaní. Dôležité miesto $\mathrm{v}$ jeho knihe zohráva pojem ideológia, ktorá vlastne využíva aktérov v škole pre vlastné reprodukovanie. Autorov prístup je zjavne holistický. Apple vysvetl'uje, ako si osvojujeme hodnoty v škole. Píše: „Hodnoty ,pracujú' skrze nás, často nevedome, a otázkou nie je ako sa postavit' ,nad' možnost' výberu, ale skôr aké hodnoty si musím nakoniec vybrat'“ (Apple, 1990, s. 9).

Michael Soldatenko (2001) zase ukázal, ako sa postupne tlakom študentov minoritného obyvatel'stva a rôznymi skupinami aktivistov inštitucionalizovali v amerických univerzitách tzv. Chicano Studies (Latino Studies). Protesty proti nerovnostiam a kritika amerického vzdelávacieho systému vyústili do vzniku osobitných štúdií v rámci vedných odborov amerických univerzít - Chicano Studies. Postupne sa Chicano Studies inštitucionalizovali na viacerých, aj významných amerických univerzitách. Kde vidí Soldatenko skryté kurikulum, je štruktúra akademického života - nuansy a pravidlá akademickej pôdy. Chicano studies sa neinštitucionalizovali v univerzitách ako mnoho iných vied postupne, vydel'ovaním a spresňovaním predmetu výskumu, ale s nejasným predmetom záujmu a s dôrazom na „právo na vlastné (kultúrne) štúdiá“. Zakladatelia Chicano studies prebrali všetky pravidlá fungovania akademického sveta a prispôsobili sa fungovaniu univerzity. Vytvorili študijné programy, definovali výskumné problémy a oblasti, avšak práve prispôsobením sa akademickým pravidlám zabudli na pôvodné plány skúmat' „tehotenstvá maloletých (minority)..., nefunkčné rodiny (minority)..., násilie mladistvých (minorít)..., vylúčených príslušníkov (minorít)..." (Soldatenko, 2001, s. 211). A d'alej: „Študenti, učitelia a výskumníci v odbore Chicano studies sa stali spoluparticipujúcimi na reprodukcii triedy, genderu, sexuálnych a rasových nerovnostiach v Spojených štátoch" (Soldatenko, 2001, s. 211). Skrytým kurikulom je takto pre Soldatenka akademický život a Chicano studies, ktoré sa mu museli pod tlakom pravidiel fungovania celku prispôsobit'.

\section{Diskusia}

Prvou otázkou, ktorá stojí v pozadí celej diskusie je, čo je dôsledkom čoho? Žiaci a učitelia svojím konaním (vedome, či nevedome) vytvárajú fenomén skrytého kurikula, teda participujú aktívne na jeho vytváraní? Alebo sociálna štruktúra skrytého kurikula pôsobí na žiakov a učitelov a tým reprodukuje 
samu seba? Učitelia a žiaci sú jednotlivci, ktorí svojím konaním vytvárajú inštitúciu skrytého kurikula a práve vd’aka ich konaniu a správaniu sa ju vidíme a vieme identifikovat'? Alebo je skryté kurikulum fenoménom takpovediac svojou povahou sui generis, jednotlivci sú jeho súčastou a konajú tak, ako inštitúcia skrytého kurikula hovorí, teda v jeho medziach?

Všimnime si však, že metodologický individualisti opisujú a kritizujú konanie aktérov v každodennosti, odhal'ujú konanie a správanie sa učitel’ov a žiakov v triede. Skryté kurikulum takto dostáva podobu aktov, ktoré vytvárajú štruktúry. Na druhej strane z pohladu metodologického holizmu vyzerá skryté kurikulum ako štruktúra či obsah, ktoré si aktéri osvojujú a stávajú sa jej (jeho) súčastou. Zároveň je nepodstatné či je štruktúra, alebo obsah súčast’ou formálneho kurikula školy (napr. vždy problematická výučba národných dejín) alebo ide o školskú každodennost' počas, či mimo priameho vyučovania (socializácia do spoločenskej triedy, do role a pod.). Domnievam sa, že nejednoznačné chápanie skrytého kurikula, ktoré som načrtol v úvode tejto štúdie, vyplýva z nejednoznačného zatriedenia a nepresného definovania dedičstva jednotlivých metodologických škôl. Preto si myslím, že dedičstvom metodologického individualizmu je hovorit' o skrytom kurikule ako o implicitnej socializácii, či učení sa prežitiu v škole, dedičstvom metodologického holizmu je definovat'skryté kurikulum ako tajné, či skrývané učebné plány, ideológiu, či mechanizmus reprodukcie.

Nie je možné povedat',že by (metodologický) holizmus a (metodologický) individualizmus boli vnútorne konzistentné. Existuje viacero individualistických a viacero holistických prístupov. Udehn (2002) rozlišuje vo svojom článku individualistické prístupy na silné a slabé. K silným zarad'uje teóriu sociálneho kontraktu (napr. Hobbes), teóriu všeobecného equilibria (napr. Smith, Mill) a teóriu rakúskeho metodologického individualizmu (napr. Mises, Hayek). Slabé sú podl'a autora popperianská teória metodologického individualizmu (Popper) a Colemanov metodologický individualizmus (Coleman). Autor vysvetl'uje toto rozdelenie tak, že pokial' v silných individualistických prístupoch sú sociálne inštitúcie endogénne súčasti sociálnych modelov a vysvetlenie ich povahy je konsekventné, tak v slabých modeloch sú už sociálne inštitúcie exogénnej povahy a ich vysvetlenie v sociálnom modeli je antecedentné. Následne Udehn (2002, s. 502) odmieta holistický prístup a hovorí, že slabé individualistické prístupy dodnes integrovali do seba holistické elementy. A toto je aj cesta, ktorú má nastúpené skryté kurikulum v súčasnosti. Príkladom takejto aplikácie môžu byt’ práce Beckera, Willisa, LeCompte a Anyon. 
H. Becker bol predstavitelom symbolického interakcionizmu (rovnako ako Mead) a označuje sa aj za predstavitela sociálneho konštruktivizmu. Jeho práca (1952) je postavená na kvalitatívnom výskume vztahov učitelov ku žiakom rozličných sociálnych tried. Becker chce ukázat’ „ako reagujú učitelia verejných škôl na kultúrne rozdielnosti, a tým udržujú diskriminujúci mechanizmus vzdelávacieho systému voči nižším triedam" (Becker, 1952, s. 452). Autor postupuje v celej analýze tak, že na podklade jednotlivých situácií, vyjadrení jednotlivcov a ich skúseností zovšeobecňuje, pričom na konaní jednotlivcov ilustruje fungovanie celku. Primárnym cielom Beckerovej práce je ukázat', ako sa jednotlivé postoje a vztahy učitel'ov voči žiakom pretavujú do fenoménu sociálneho usporiadania spoločnosti. Podobnú kritiku s podobným metodologickým vysvetlením uplatnil Willis (1977) o štvrt'storočie neskôr.

Willis (1977) a o rok neskôr už spomenutá LeCompte (1978) sú d’alšími autormi individualistickej perspektívy, ktorí čerpajú inšpiráciu v sociálnych nerovnostiach $\mathrm{v}$ spoločnosti, ktoré podla ich názoru vyplývajú z existencie výchovno-vzdelávacej inštitúcie (a organizácie) školy v spoločnosti. Ich štúdie hovoria o učení sa pracovat' už v škole. Štúdie analyzujú v každodennosti života žiakov (deti) v škole, ich stratégie vzdorovania školskému systému voči učitel'om a školskému systému (Willis, 1977). Rozoberajú stratégie, akými sa v škole postupuje, aby sa dosiahol žiadaný ciel', teda človek pripravený a prispôsobený pre industriálny (či aplikovaný pre dnešok - tak často nazývaný „vedomostný“ - kritizovaný, napr. Kaščákom \& Pupalom, 2010) pracovný proces (LeCompte, 1978). Obe práce, prechádzajú od popisu individuálneho správania sa a konania jednotlivcov ku kritike a k zovšeobecňovaniu na úrovni celej spoločnosti - systému. Autori však vysvetl'ujú dva rôzne spoločenské fakty. Willis uprel svoj pohlad na vytváranie spoločenskej štruktúry cez odraz vlastnej identity jednotlivca v tejto štruktúre, teda stotožnenie sa s miestom v štruktúre. LeCompte cieli na vytváranie „kultúry práce“ sledovaním jej mikroštruktúr. „Detské miesto práce je škola, neurčuje len úspešnost' na pracovnom trhu, ale zasahuje aj do toho, čo si myslí žiak sám o sebe (ako chápe sám seba)“" (LeCompte, 1978, s. 35).

Ďalšou autorkou, ktorá metodologicky postupuje tak, že nazbierané údaje z výskumu by sme jednoznačne označili ako kvalitatívne, je J. Anyon. Fenomenologický, či skôr etnometodologický prístup pri zbieraní údajov zúročila autorka vo vysvetlovaní kritickým prístupom, v ktorom sa jednoznačne ukazuje inšpirácia marxistickou školou. Anyon (1980) si vybrala pre výskum pät' 
škôl, pričom podla stanovených kritérií rozdelila školy na tie, do ktorých chodia deti pracujúcej triedy, deti stredných tried, deti z rodín vplyvných „profesionálov" a nakoniec školu, do ktorej chodia deti „výkonnej elity“. Vychádzala z presvedčenia, že existujú triedne podmienené rozdiely vo vyučovacom procese. Následne sledovala konkrétne učebné štýly a spôsoby práce so žiakmi. Na základe zisteného $\mathrm{v}$ každodennosti školskej triedy mohla urobit’ závery o reprodukcii tried $v$ spoločnosti a potvrdit’ svoje hypotézy.

\section{Záver}

Dnes pri neustálych za sebou nasledujúcich reformách školstva riešime otázky kultúrnych a sociálnych nerovností v škole, ktoré sme obmedzili len na skúmanie socio-ekonomických znakov rodiny, namiesto otázok rovnosti podmienok nás často trápia otázky rovnosti príležitostí, namiesto kvality vzdelávania na všetkých úrovniach školstva sa ovela častejšie diskutuje o kvantitatívnych ukazovateloch vzdelávania. Pred 40 rokmi to boli už spomenuté výskumy skrytého kurikula od Beckera, Geer a Hughesa (1968, cit. 1995), Snydera (1971) a Millera a Parletta (1974), ktoré boli rámcované do kontextu úspešnosti žiaka a skrytého kurikula. Bauman v najnovšej knihe vyjadril presvedčenie, že redefinovanie úspechu v škole a preneseniu zodpovednosti za známky zo študenta na učitela je jedným z dôsledkov ideologickej zmeny ktorú momentálne prekonávame. Školstvo, vzdelávanie a výchova sa čím d'alej viac podriad'uje diskurzu trhu a trhovým princípom a je potrebné hladat' vinníka zlyhávania systému, ktorým sa stáva učitel' (Bauman \& Mazzeo, 2012).

Teória skrytého kurikula je napadnutel'ná pokial' podrobuje realitu výskumu len z pozície holizmu a rovnako tak je nepoužitel'ná pokial' zostáva na úrovni individualizmu a jej poznatky nie je možné generalizovat' na vyššiu úroveň. Dnes vieme o skrytom kurikule dost' aby sme vedeli, že holizmus a individualizmus je t'ažké od seba oddel'ovat'. Sú to skôr komplementárne, ako alternatívne cesty poznávania. Prístupy a meranie skrytého kurikula sa rôznia v závislosti od teórie, s ktorou vstupuje výskumník do terénu, a od výskumníka samotného ako aj jeho presvedčenia. Výber teórie a presvedčenie výskumníka už predpokladajú aj metodologický postup a následne ovplyvňujú definovanie samotného skrytého kurikula a získané údaje. $V$ konečnom dôsledku ovplyvňujú aj teóriu toho, čo skryté kurikulum je a za čo sa považuje. Nemožno však povedat', že jeden prístup je lepší ako ten druhý. 
Postavenie výskumu na individualistickom základe, teda nastavenie, meranie a sledovanie skúmanej reality fenomenologicky či etnometodologicky je stabilnou základňou pre holistické vysvetlovanie skúmanej reality. Metodologickí holisti (a tu sa môžeme pozerat' ako na funkcionalizmus, tak aj na marxizmus, či štrukturalizmus, ktorý z neho vychádza atd'.) sa odvolávajú na indivíduá ako na aktérov slúžiacich štruktúre. Netreba zabúdat', že skryté kurikulum je vo všeobecnosti predovšetkým tematizované ako problematické pri skúmaní sociálnych a kultúrnych nerovností. Individualistický pohlad však dokáže ukázat' subjektívne prežívanie reality v štruktúre, pohl'ad na štruktúru a jej subjektívnu interpretáciu. Rovnako tak aj na vztahy vo vnútri štruktúry, jej stavbu a vnútornú dynamiku. Štrukturalizmus nám zopakoval starú tézu, že „objektívna“ realita neexistuje. Realita prežívaná jednotlivcom je ním vytváraná do tej miery, do akej ju jednotlivec chápe ako reálnu a pravdivú. Skryté kurikulum je ako výskumný problém l’ahko uchopitel'ný a operacionalizovatel'ný pre výskum, ktorý môže skúmat' život školskej triedy a prežívanie každodennej reality v škole. Zároveň môže ale robit’ bernsteinovské závery o jazyku súčasnej ekonomiky a jeho mieste v živote školy a školstva.

\section{Literatúra}

Althusser, L. (2008). On ideology. London: Verso.

Anyon, J. (1980). Social class and the hidden curriculum of Work. Journal of Education, 162(1), 67-92.

Apple, M. W. (1990). Ideology and curriculum. London: Routledge.

Bauman, Z., \& Mazzeo R. (2012). On education: Conversations with Riccardo Mazzeo. Cambridge, Malden: Polity Press.

Becker, H. S. (1952). Social-class variations in the teacher-pupil relationship. Journal of Educational Sociology, 25(8), 451-465.

Becker, H. S., Geer, B., \& Hughes, E. C. (1995). Making the grade. New Brunswick, London: Transaction Publishers.

Bergenhenegouwen, G. (1987). Hidden curriculum in the university. Higher Education, 16(5), 535-543.

Bourdieu, P., \& Passeron, J.-C. (1964). Les héritiers: les étudiants et la cultura. Paris: Les Editions de Minuit.

Bourdieu, P., \& Passeron, J.-C. (1990). Reproduction in Education, Society and Culture. London, Thousand Oaks, New Delhi: Sage Publications.

Bourdieu, P. (1998). Teorie jednání. Praha: Karolinum.

Corsaro, W. A. (1988). Peer culture in the preschool. Theory into Practice, 27(1), 19-24.

Costello, C. Y. (2001). Schooled by the classroom. In E. Margolis (Ed.), The hidden curriculum in higher education (s. 43-59). New York, London: Routledge. 
Fay, B. (2002). Současná filosofie sociálních věd. Praha: Slon.

Garfinkel, H. (1967). Studies in ethnomethodology. New Jersey: Prentice-Hall, Inc.

Giroux, H. A., \& Penna, A. N. (1979). Social education in the classroom: The dynamics of the hidden curriculum. Theory and research in Social Education, 7(1), 21-42.

Giroux, H. A. (1981). Ideology, culture, and the process of schooling. Philadelphia: Temple University Press.

Goffman, E. (1974). Frame analysis. Cambridge: Harvard University Press.

Goffman, E. (1999). Všichni hrajeme divadlo. Sebeprezentace v každodenním životě. Praha: Ypsilon.

Havlík, R., \& Kotáa, J. (2007). Sociologie výchovy a školy. Praha: Portál.

Illich, I. (1973). After deschooling, what? In A. Gartner, C. Greer, \& F. Riessman (Eds.), After deschooling, what? (s. 1-28). New York: Harper \& Row.

Jackson, P. W. (1966). The student's world. The Elementary School Journal, 66(7), 345-357.

Joughin, G. (2010). The hidden curriculum revisited: A critical review of research into the influence of summative assessment on learning. Assessment \& Evaluation in Higher Education, 35(3), 335-345.

Kaščák, O., \& Filagová, M. (2007). Javisko a zákulisie školy. O materskej škole a skrytom kurikule. Trnava: Typi Universitatis Tyrnaviensis.

Kaščák, O., \& Pupala, B. (2010). Neoliberálna guvernmentalita v sociálnom projektovaní vzdelávania. Sociologický časopis, 46(5), 771-799.

Langhout, R. D., \& Mitchell, C. A. (2008). Engaging contexts: Drawing the link between student and teacher experiences of the hidden curriculum. Journal of Community and Applied Social Pychology. 18(6), 593-614.

LeCompte, M. D. (1978). Learning to work: The hidden curriculum of the classroom. Anthropology and Education Quarterly, 9(1), 23-37.

Maňák, J., \& Janík, T. (2009). Kurikulum. In J. Průcha (Ed.), Pedagogická encyklopedie (s. 117-121). Praha: Portál.

Mareš, J., \& Rybářová, M. (2003). Skryté kurikulum - málo známy parametr klimatu vysoké školy. In S. Ježek (Ed.), Psychosociální klima školy I. (s. 99-122). Brno: MSD.

Matus, C., \& McCarthy, C. (2003). The triumph of multiplicity and the carnival of difference: Curriculum dilemmas in the age of postcolonialism and globalization. In W. F. Pinar (Ed.), International handbook of curriculum research (s. 73-82). Mahwah, New Jersey, London: Lawrence Erlbaum Associates.

Mead, G. H. (1934). Mind, self, and society. Chicago: The University of Chicago Press.

Miller, C. M. L., \& Parlett M. (1974). Up to the mark: A study of the examination game. London: Society for Research into Higher Education.

Německý, M. (2008). Funckionální vysvětlení v sociálních vědách. In J. Šubrt et al., Soudobá sociologie II (Teorie sociálního jednání a sociální struktury) (s. 164-184). Praha: Karolinum.

Ondrejkovič, P. (1998). Úvod do sociológie výchovy. Bratislava: VEDA.

Ondrejkovič, P. (2004). Socializácia v sociológii výchovy. Bratislava: VEDA.

Petrusek, M. (2000). Etnometodologie. In M. Petrusek, A. Vodáková, \& A. Miltová (Eds.), Sociologické školy, směry a paradigmata (s. 175-177). Praha: Slon.

Prosser, J. (2007). Visual methods and the visual culture of schools. Visual studies, 22(1), 13-30.

Průcha, J. (2002). Moderní pedagogika. Praha: Portál 
Rios, D. (2005). Social complexity and the micro-macro link. Current Sociology, 53(5), 773-787. Schenk, J. (2009). Émile Durkheim a problém emergencie: silná, slabá a semi-silná emergencia. In Z. Kusá \& M. Tížik (Eds.), Elementárne formy sociologického myslenia (s. 75-99). Bratislava: Sociologický ústav SAV.

Smith, D. G. (2003). Curriculum and teaching face globalization. In W. F. Pinar (Ed.), International handbook of curriculum research (s. 35-51). Mahwah, New Jersey, London: Lawrence Erlabaum Associates.

Snyder, B. R. (1971). The hidden curriculum. New York: Knopf.

Soldatenko, M. (2001). Radicalism in higher education. In E. Margolis (Ed.), The hidden curriculum in higher education (s. 193-212). New York, London: Routledge.

Švec, Š. (2008). Anglicko-slovenský lexikón pedagogiky a andragogiky. Bratislava: IRIS.

Udehn, L. (2002). The changing face of methodological individualism. Annual Review of Sociology, $28,479-507$.

Wagner-Willi, M. (2005). Kinder - Rituale zwischen Vorder- und Hinterbühne: Der Übergang von der Pausezum Unterricht. Wiesbaden: VS Verlag für Sozialwissenschaften.

Willis, P. (1977). Learning to labour - how working class kids get working class jobs. New York: Columbia University Press.

Zinnecker, J. (1978). Die Schule als Hinterbühne oder Nachrichten aus dem Unterleben der Schüler. Berichte und Bilder vom Lernalltag von Lern pausen und vom Lernen in den Pausen. Reinbek: Rowohlt.

\title{
Autor
}

Mgr. Lukáš Bomba, Žilinská univerzita v Žiline, Fakulta humanitných vied, Katedra pedagogických štúdií, Univerzitná 8215/1, 01026 Žilina,

e-mail: lukas.bomba@fhv.uniza.sk

\section{Hidden curriculum in the light of methodological holism and methodological individualism}

\begin{abstract}
The article analyses theoretical and methodological problem of hidden curriculum at school. It compares individualistic and holistic approach in connection to research, measurement and analysis of hidden curriculum. The goal of the study is to present the inconsistency in understanding and explaining the concept of hidden curriculum. The inconsistency is grounded in the absence of paradigmatical background. The theories of hidden curriculum are devided into two groups. The first group is grounded in individualistic approach and the second group is grounded in holistic approach. The examples of empirical studies are used as tools to grasp hidden curriculum at school. The study concludes that the definitions and understanding of the concept of hidden curriculum are logical conclusions of methodological approach and empirical investigation of hidden curriculum in research. The methodological
\end{abstract}


approach and empirical investigation reversely constitute the theory of hidden curriculum. The individualistic paradigm grasps hidden curriculum as a an implicit socialization of a child through the actions of individuals in the school. The holistic paradigm understands hidden curriculum as institutionalized nature of ideology or the tool for reproduction of society.

Keywords: hidden curriculum, school, methodological individualism, methodological holism

Pol, M., Hloušková, L., Lazarová, B., Novotný, P., \& Sedláček, M. (2013). Když se školy učí. Brno: Masarykova univerzita.

Publikace se zabývá organizačním učením ve školách. Autoři nejdříve zmapovali dosavadní výzkumy a teorie spojené s organizačním učením obecně a specificky pak s organizačním učením ve školním prostředí - o tom pojednávají v úvodní kapitole. Poté informují o empirickém výzkumu, který se znalostí teorie a výzkumů provedli na základních školách v České republice. Pro tento účel byl využit smíšený výzkumný design - v kvalitativní fázi šlo o vícečetnou př́padovou studii, kvantitativní fáze proběhla cestou dotazníkového šetření. Tím se podařilo získat řadu významných poznatků o procesech organizačního učení a jejich vedení a řízení. Další části publikace tak přinášejí informace o obsahovém zaměření a strukturním uspořádání organizačního učení ve školách, o jeho aktérech a způsobech podpory. Zvláštní pozornost věnují autoři podpůrným faktorům organizačního učení a také některým morálním dilematům spojeným s vedením a řízením procesů organizačního učení ve školách.

\section{Studia paedagogica 2/2012}

Nové číslo časopisu Studia paedagogica přináší několik studií, které se dotýkají především institucionálních charakteristik školního života. Zařazen je rovněž rozhovor s prof. Christophem Wulfem na téma vlivu školní kultury - a v ní obsažených fenoménů jako jsou emoce či rituály - na kvalitu školy. Z obsahu: D. Dvořák: Nový institucionalismus v pedagogice. M. Sedláček a kol.: Organizační učení v realitě školy. S. Davidsdottir, P. Lisi: Spolupráce učitelů a jak ji podněcovat (poznatky z longitudinální a průřezové studie interní evaluace na Islandu). J. Bradová: Ked' zasadací poriadok funguje alebo Učitel'sko-žiacke preferencie při obsadzovaní priestoru školskej triedy. M. Klusák: K roli her v morálním vývoji dítěte podle teorie Jeana Piageta.

http://www.phil.muni.cz/journals/index.php/studia-paedagogica 